https://artnodes.uoc.edu

\title{
The Video, the City, and the Spectator: Architecture and Its Bodies in Front of a Video Camera
}

\section{Lorenzo Lazzari}

University of Udine

Date of submission: September 2020

Accepted in: December 2020

Published in: January 2021

\section{Recommended citation}

Lazzari, Lorenzo. 2021. «The Video, the City, and the Spectator: Architecture and Its Bodies in Front of a Video Camera». In: Benítez, Laura; Berger, Erich (coord.) «Arts in the time of pandemic». Artnodes, no. 27: 1-9. UOC. [Accessed: dd/mm/yy]. http://doi.org/10.7238/a.v0i27.373933

\footnotetext{
The texts published in this journal are - unless otherwise indicated - covered by the Creative
Commons Spain Attribution 4.0 International license. The full text of the license can be consulted here:
Sttp://creativecommons.org/licenses/by/4.0/
}

\begin{abstract}
This paper is an investigation into the kinds of spectatorial relationships that could be generated when a moving image (video, in this case) presents a city within a political framing. To this end I will analyse three different case studies in which the city-its architecture, and its population-is the polemical common ground of the artwork: Guilty Landscape episode I-Hangzhou by Dries Verhoeven (2016), Sign on a Truck by Jenny Holzer (1984), and Història Urbanística by Video-Nou (1978). In my argumentation, I will adhere generally to Jean Baudrillard's conceptualisations in terms of media "responsibility", and those of Jacques Rancière when focused on the term "dissensus", understood as the essence of politics. Importantly, and worth emphasising, all moving image works are able to mirror the spectator who, through different devices and spatial settings, becomes an active part of the representation itself: and a representation that does not require a form of response is a curtailment that does nothing but amplify the decision-making power of the powerful. Instead, Dries Verhoeven, Jenny Holzer, and Video-Nou confront us with their representations and bid us towards an active personal participation in its construction. Moreover, this could be considered as a reflection upon what might feasibly be achieved today in architecture and urban representation through various new media and their intersections with the moving image and performative arts.
\end{abstract}




\title{
artnodes
}

https://artnodes.uoc.edu

The Video, the City, and the Spectator: Architecture and Its Bodies in Front of a Video Camera

\section{Keywords}

Moving image, architecture, video, political action, spectatorship

\author{
El vídeo, la ciudad y el espectador: \\ La arquitectura y sus cuerpos ante una cámara de vídeo
}

\begin{abstract}
Resumen
Este artículo es una investigación sobre los tipos de relaciones de espectadores que se pueden generar cuando una imagen en movimiento (video, en este caso) presenta una ciudad dentro de un marco político. Con este objetivo analizaré tres estudios de caso diferentes en los que la ciudad -su arquitectura y su población-es el terreno polémico común de las obras Guilty Landscapes, episode I - Hangzhou, de Dries Verhoeven (2016); Sign on a Truck, de Jenny Holzer (1984); e Història Urbanística, de Video-Nou (1978). En mi argumentación seguiré, principalmente, las reflexiones de Jean Baudrillard sobre la «responsabilidad» mediática, y a la de Jacques Rancière cuando se centra en el término "dissensus» entendido como la esencia de la política. Es importante, y vale la pena subrayarlo, que todas estas obras de imagen en movimiento pueden reflejar al espectador, que a través de varios dispositivos y de configuraciones espaciales, se convierte en una parte activa de la representación misma: y una representación que no requiere una forma de respuesta es una reducción que no hace más que amplificar el poder de la toma de decisiones de los poderosos. En cambio, Dries Verhoeven, Jenny Holzer y Video-Nou, nos enfrentan con sus representaciones y nos proponen una participación personal activa en su construcción. Además, esto podría considerarse como una reflexión sobre lo que se podría lograr actualmente en arquitectura y representación urbana a través de varios nuevos medios y sus intersecciones con la imagen en movimiento y las artes escénicas.
\end{abstract}

\section{Palabras clave}

Imagen en movimiento, arquitectura, vídeo, acción política, condición de espectador

\section{Introduction}

The act of expanding architectural practice compared with the mechanisms of social agency, urban action, and participatory practices requires some deliberation upon which systems of representation are able to accommodate, encode and convey those new subjects, as revealed whenever such comparisons are made. Seeking to reinstate these practices by employing the discipline's conventional techniques of representation-such as parallel projections, collages, perspective drawings-risks being reductive, especially when confronted with an "agency", defined as the ability of a structured action to change the state of affairs from within the system in which the oppressed community is acting (Butler 2017, 41-42). Jean Baudrillard, in Requiem for the Media, defines responsibility as the space in which whoever speaks-that is, the one who performs the act of representation, codifying the actions into symbols-is able to receive an immediate response from the represented subject which is, therefore, an agent of the same representation. On the other hand, irresponsibility is the condition of those who give but cannot receive; of those who speak but cannot listen (or who cannot be answered). The balance of communication and antagonistic reciprocity fails (Baudrillard 1986,
124-143) and therefore, as we will see later, so do the principles of political action.

Funnelling all architectural representation exclusively into architectural drawing, when we are arguing about bodies that act on space, results in losing that degree of interactivity necessary for each participatory process. The risk is, as Bernard Tschumi articulated in The Manhattan Transcripts, that models of representation would be "caught in a sort of prison-house of architectural language, where the limits of my language are the limits of my world" (Tschumi 1994, 9). Therefore, in discussing this exigency for responsibility ("not a psychological or moral responsibility, but a personal, mutual correlation in exchange") (Baudrillard 1986, 128) in architectural representation, I will endeavour to expand the horizon of its language, using three examples that go beyond the discipline-referring in particular to the world of moving images-but whose subject is still the city and its political common space. Guilty Landscape episode I (2016), Sign on a Truck (1984) and Història Urbanística (1978) are quite distant from each other both temporally and geographically (Hangzhou, New York, Barcelona respectively), but they share a possible reading that unites them: that of considering their own responsibility with (not on) the subjects represented. 


\section{artnodes}

https://artnodes.uoc.edu

The Video, the City, and the Spectator: Architecture and Its Bodies in Front of a Video Camera

The three works are here discussed within the perspective of considering the tools of representation, used by visual and performing arts, as possible reading-layers for the city as an ensemble project. This is particularly pertinent when the narration tries to give an account of the bodies that inhabit it, more-over to count-an idea that sees in democracy an equal opportunity of everyone to say and act-the part "of those who have no part in anything" (Rancière $1999,9)$ on which its politics is founded. By arguing through the case studies, the way in which they make explicit the creative process of representation through the representation itself should become clear, in a sort of mise en abyme. In other words, these are images that not only put contents into form but that in themselves make the construction of that same form visible.

\section{Destroying the Spectatorship}

Within the context of Santarcangelo Festival 2019 (an Italian theatre and performing arts festival held for fifty years in Santarcangelo di Romagna, near Rimini), episode I-Hangzhou, of the Guilty Landscapes series (2016) by Dries Verhoeven (Netherlands) had its showcasing. Guilty Landscapes consists of an additional three episodes, each titled with the name of a particular city: II-Port-au-Prince, III-Homs, IV-Pattaya. Since this work is a performance for a single spectator, and can undergo variations each time, lasting a maximum of ten minutes, a first person description is ineluctable.

Without any intimation or explanatory leaflet, I found myself alone in front of a screen that took up the entire height of the back wall of a vast gloomy room. The video projection displayed a long line of industrial machines operating inside a textile factory (presumably in Hangzhou, China). The clangour of the machinery, spinning incessantly at a frenetic pace, reverberated throughout that voluminous space. A black carpet lay on the ground, not far from the screen. The performative space seemed to have been supplanted by an exhibition zone allocated to the projection of moving images, as might well be found in any contemporary art expo. Focusing on the video, however, I realised that something was not quite right with the projected image. Not in the sense of shoddy image construction, but in the sense that there was some detail-not yet clearly perceptible-that produced in me a sensation of incongruity. The only certainty-for a European spectator-was that nobody would wish to find themselves in such a terrifying place as being depicted on the screen. However, the exhibition space and the familiar screen device made me feel safe from that other place, far from any possible danger. The screen was apprehended as a giant transparent and indestructible wall. Nevertheless, as I continued to watch, one lingering qualm had not yet been addressed: where is the performance?

On turning around I noticed a lectern upon which was a sheet of paper. I had not been aware of it on entering. The constituent elements of the performance had been listed: video projection, internet connection, video camera, two performers. I returned to watching the projection. Something seemed detached from the bottom of the image and positioned itself on the vanishing point: a worker was watching me from the screen. The figure assumed the same posture as me. I stepped forward and so did the operative, towards me. At that precise moment, the security that was given by the exhibition space and the screen-as devices that ought to have placed me away from that terrible place-suddenly collapsed, making me feel involved in some way with that reality; another conundrum solved: the second apparently invisible performer listed in the call sheet must be the spectator. So that screen, which should have kept the representation away, was watching and asking for me.

I approached the screen, and so did the other performer. I made out her feminine traits. I started testing the edges of the representation, moving to the wall on the right. The performer did the same, stopping only when she was about to collide with one of the machines. So was she really in that factory? Or was it a chroma key trick? The performer then put on earmuffs and the racket of the machines became muffled for me too: the sensation of sharing the same space beyond the screen became all embracing. With this gesture, the worker stopped copying my postures and instead invited me to respond to her movements: the representation questioned the spectator. So, following her step by step, I lay down with her beside the screen, where I could at last glimpse the small closed-circuit camera that had been watching me from the beginning of the performance. The woman on the other side of the screen presented her hand as if seeking physical contact. I moved mine towards the screen, but nothing could happen except that, by blocking part of the video light, it projected my hand's shadow onto the screen, thereby obscuring her open palm on the other side. The illusion of that possible sharing of space between me and the image was extinguished. Moving images returned to the screen's domain, and the spectator's body to the safe space of an exhibition, at a festival, in Italy, in Europe.

Noam M. Elcott affirms that "when real time prevails over real space, real space becomes phantasmagoric, an assembly of bodies and images" (Elcott 2016, 57). The category of phantasmagoric, at variance with the cinematic one, does not deprive the viewer of their body and their surrounding space (to make it focus on the unidirectionality of frontal projection), but makes them its own in the opera, since it shares the same space as the observer. However, the substantial difference between the phantasmagoric device described by Elcott and the one which Verhoeven staged in Guilty Landscapes, lies in the fact that it is not so much the projected image brought into our domain, but it is our bodily perception that is transported to the place beyond the screen through another device: guilt. Theresa Schütz, who attended episode II-Port-au-Prince, commented on this feeling: "I, as the counterpart of this encounter, develop feelings of shame and guilt because of my personal failure to render assistance, while at the time I blame (and frame) myself for living my western life of wealth, which rests upon the exploitation of the global south" (Schütz 2019, 185-186). The guilty landscape is not, therefore, the scenario in which the performer is located beyond the screen, but the space here, mental and physical, 


\section{artnodes}

in which we find ourselves as spectators who, as related by the Susan Sontag excerpt that is delivered at the end of the performance, can be connected to those desolate landscapes and characters "in ways we might prefer not to imagine" (Sontag 2003, 90-93).

In the same excerpt, Sontag argues that today the hyper-diffusion of images of war, catastrophes, and poverty through the mass media doesn't build a reflection in the viewer about the responsibilities one has with those images, but a rash urge towards compassion that makes us mistakenly feel innocent about what is being represented: "Such images cannot be more than an invitation to pay attention, to reflect, to learn, to examine the rationalizations for mass suffering offered by established powers. Who caused what the picture shows? Who is responsible? Is it excusable? Was it inevitable? Is there some state of affairs which we have accepted up to now that ought to be challenged? All this, with the understanding that moral indignation, like compassion, cannot dictate a course of action. [...] So far as we feel sympathy, we feel we are not accomplices to what caused the suffering. Our sympathy proclaims our innocence as well as our impotence. To that extent, it can be (for all our good intentions) an impertinent-if not an inappropriate-response" (Sontag 2003, 90-93). ${ }^{1}$

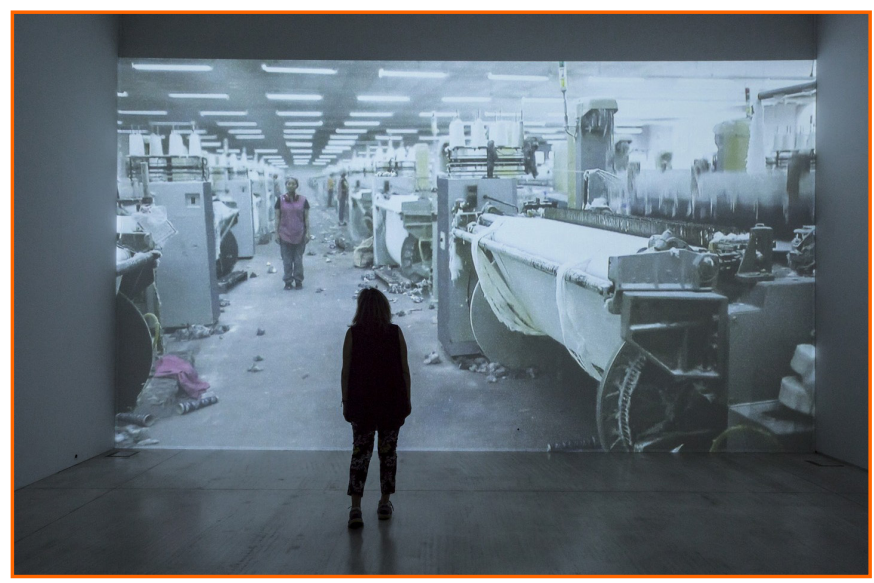

Image 1: Verhoeven, Dries, 1976-. 2016. Guilty Landscape: Episode I - Hangzou. http:// greekfestival.gr/wp-content/uploads/2018/03/Dries_Verhoeven_Guilty_Landscapes_ SITE_03_photo_Pinelopi_Gerasimou.jpg. Photography: Pinelopi Gerasimou. Courtesy: Dries Verhoeven Studio.

\section{Configuring the Space}

Two days before the 1984 US presidential election, which would see Ronald Reagan as the winner for the second time, Jenny Holzer put on a video installation in two different locations of Manhattan, one in midtown (Grand Army Plaza) and the other in downtown (Bowling Green Plaza). Sign on a Truck is a massive $12.5 \mathrm{ft} \times 18 \mathrm{ft}$ colour display, mounted on the trailer of a 5-axle truck, which showed a combination of live interviews and prerecorded videos by artists that Holzer had invited to collaborate, including Vito Acconci, Leon Golub, Keith Haring, Claes Oldenburg and Jenny Holzer herself (Public Art Fund, n.d.). While the messages by artists such as Acconci or Haring took on a tone of explicit criticism and ridicule of Reagan, the open sessions encouraged the participation of a heterogeneous public that shared its political opinion about the election. Through the video-feedback on the big screen, passersby who decided to take the floor were not only seen and listened to, not only could they see and hear themselves, but they could see being seen and hear being heard "in the process of forming a visual and verbal representation of the political reality of the viewers" (Buchloh 1985, 24).

Holzer created a sophisticated psychological feedback device in which video, together with the space of the square, played a fundamental role in constructing a process of extrospection in the viewer: one sees and listens to oneself from the outside with the knowledge that those words and one's own image are simultaneously reverberating in the public space, determining a responsibility, since one's statements-that previously did not belong to the political sphere-are now audible and visible; so they require a response, assent or dissent. It means bringing political communication out of the unidirectional space of television, understood as the physical, domestic and patriarchal space in which the proselytism of consumption and depoliticisation acts on the spectator, without allowing one to respond. As David Joselit affirms: "In the age of television, politics is conducted through media-generated icons designed to manufacture consent" (Joselit 2007, IX).

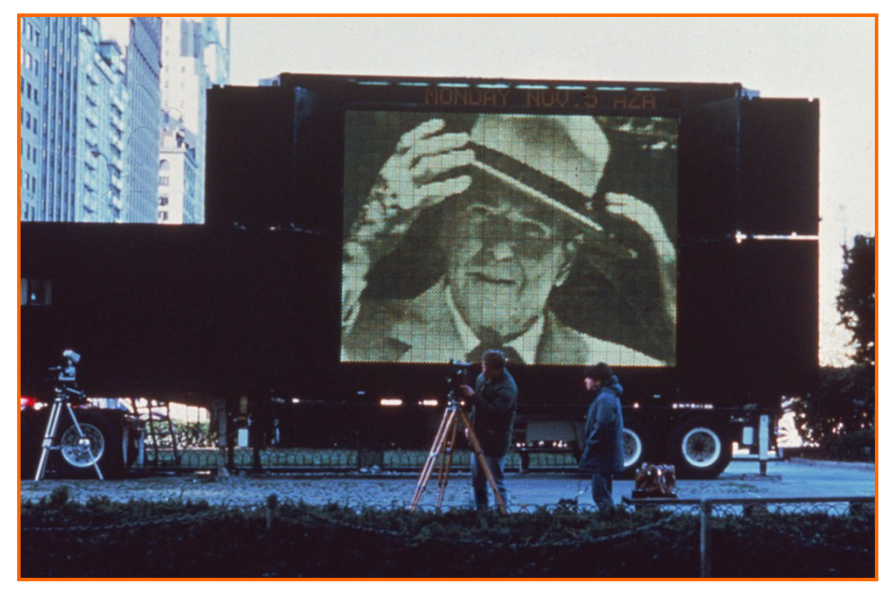

Image 2: Holzer, Jenny, 1950-. 1984. Sign On a Truck. https://library.artstor.org/asset/ARTSTOR_103_41822003096797. @ 2007 Jenny Holzer / Artists Rights Society (ARS), New York.

By way of a projection on that large public screen of what was culturally perceived as TV imagery in interview format, spectators who

1. Quoted text delivered at the end of the performance. 


\section{artnodes}

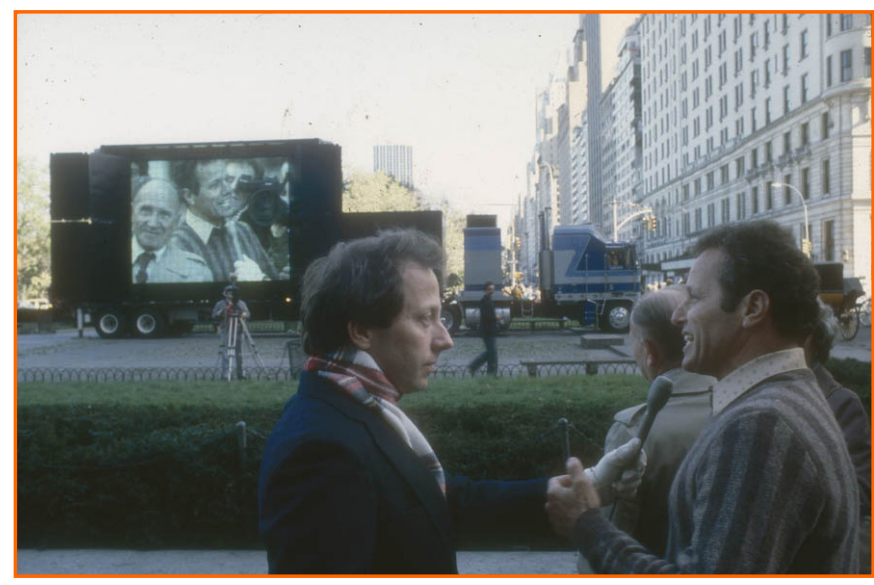

Image 3: Holzer, Jenny, 1950-. 1984. Sign On a Truck. Photo: Kevin Noble. https://www. publicartfund.org/wp-content/uploads/2019/06/HolzerJ_0847.jpg. @ P Public Art Fund.

declared themselves in favour of Ronald Reagan were perceived on the one hand as white middle-class stereotypes, "of the ideological state apparatuses as they have been internalized, the synthesis of prejudice and propaganda, of aggressive ignorance and repression, of cowardice and opportunism" (Buchloh 1985, 224), but on the other "they may recognize and understand their own conditions" (Buchloh 1985, 224). The video device staged by Holzer magnified the private interview into the scale of the public square and multiplied its close-up gaze-between interviewer and interviewee-to the external view of passersby. Through a mechanism of representation, that space comes to take shape, which for Rancière is essential to politics itself; that space in which its subjects are finally visible; in which the relationships established between the visible and the sayable are reorganised (Rancière 2011, 15).

Holzer's work also opens up a reflection on what the "public" is and what "publicness" of a city is. For Michael Warner, "A public is a space of discourse organized by nothing other than discourse itself". It exists only to the extent that an object is addressable to activate that discourse. Its quality of "publicness" is such only when it is selforganised through discourse, independently of preconstituted external frameworks, laws, or institutions. The position, function, and capacity of each member of that public cannot be specified a priori by the apparatuses of power-such would be "the image of totalitarianism: non-kin society organized by bureaucracy and law". (Warner 2002, 65-70). In Sign on a Truck, Holzer addresses a topic of discussion (Reagan's political agenda) to the common space of the square through an ad hoc device that breaks the framework of television debates, statistical polls, propaganda. Instead of being placed in front of monitors in which the content is preformed by televisual montage, spectators find themselves here as active participants in the construction of a space for the circulation of discourse. That is-as Holzer reminds us-the practicability of that founding "publicness" of the public space of the city.

\section{Questioning the Representation}

Video-Nou (1977-78)-which later became Servei de Vídeo Comunitari (1979-83)-was a Catalan collective formed in the unstable phase of the Spanish transition to democracy, in the turbulent years immediately following the death of dictator Francisco Franco in 1975. This interdisciplinary group-members came from architecture, urban planning, sociology, fine arts, economics, pedagogy, and the antipsychiatric movement-began to make use of the then-innovative medium of video. Unlike film, video and its associated apparatus made instant feedback from the camera output obtainable. They utilised this immediacy in order to access the political and social context of Barcelona at the time, planning media situations in the city that required the participation of local communities in a process of building an image of the city (Ameller 1999, 45-48). It was a conjunct of media and political practices, of social interaction devices able to include communities in the production of a dialogical image that could bypass the official communication channels: "the video medium offered in this sense the possibility of abolishing the divisions between producer and consumer, a continuous and immediate remodeling of information and the possibility of response and participation, compared to the monolithic unidirectionality of state television" (Escobar 1981, 23).

Perhaps the best example among the participatory video-interventions realised by Video-Nou/SVC, Història Urbanística (Projecte Can Serra) in 1978 is one that shows the city as a whole yet made up of two parts, inextricably linked to each other: the city in its planimetric, material and volumetric constitution (or the ville depeuplée) (Cavalletti $2005,45-51$ ), and the city understood as its populace-the bodies that inhabit and enact it. The tape begins with a slow pan from the base of barrio Can Serra's metro station. The arrival of a train accompanies the camera's eye, allowing us to observe enormous buildings, identical to each other regardless of the topography. With a jump cut, the panorama continues from another position, this time framing the buildings from above. Then the voice of one of the group's members begins to tell of the construction of that dormitory-suburb, designed to house the masses of workers who had moved to the outskirts of the Catalan city from rural areas of the country, in order to labour in its prodigious factories.

The report is accurate in providing numbers, statistics, and the occupations of the locals. A series of interviews with the older inhabitants of the neighbourhood reveals the recent urbanisation of the barrio, previously formed by just farmland and low-rise housing. The interviews have a spontaneous character, and the members of the group establish, from time to time, a dialogue based on the answers given about the neighbourhood. These interviewees, gaining confidence, reveal the dynamics of current real estate speculation: foundations on backfill; revisions to building plans which fail to take into consideration the ratio between a growing population density and the availability of primary services; blocks built without even cursory urban planning; municipal architects that were simultaneously employed by private 


\section{artnodes}

construction companies. In short: architecture as a crime. ${ }^{2}$ All this is directly documented by citizens, who complain about the problems caused to their daily lives by the appalling management of Can Serra. Not only does it entail the surveying of a myriad of structural problems in the new buildings, but also the inconsistencies between building plans and building facts. As a neighbourhood association, they lodged a complaint with the municipality: it was a concrete political act, cognisant that the operational management of the city cannot be distinct from politics.

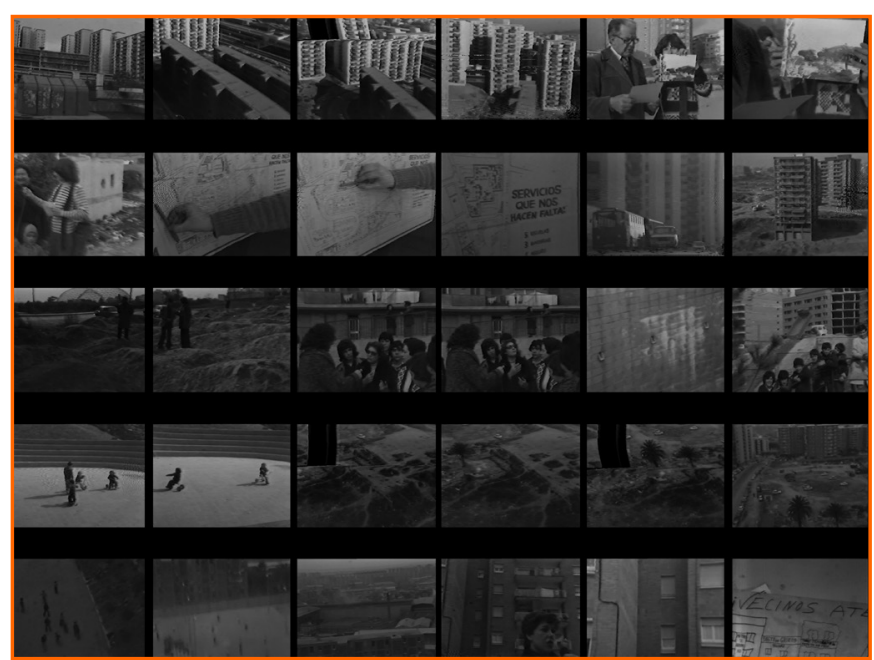

Image 4: Video-Nou, 1977-1979. 1978. Història urbanística (projecte Can Serra). Stills from video, b/w, sound, $41 \mathrm{~min}$. Full video available at https://www.hamacaonline.net/titles/ historia-urbanistica-projecte-can-serra. (C) Hamaca.

According to Guy Debord, the alienation of the spectator from his existence and his real desires is due to the receding of life experience into only a representation, which became independent from the subject represented and therefore pure spectacle. The spectator does not recognise his gestures because it is another that represents them to him in the form of a show (Debord 2013, 53-63). Alternatively, Video-Nou/SVC aimed for liberation from the condition of being a spectator through "the authorial reappropriation of media tools by the communities themselves which in this way, from a mere documentable object, they would have become agents of their own representations" (Carrillo 2005, 67). The device set in motion by the collective, in order to make the feedback theory operational, was the Video-Bus. This was a mini-bus, modified in order to be autonomous for both editing and screening videotapes, thanks to a CRT TV system that appeared from the vehicle's windows. In this way, the participatory documentary was put back on display inside the very same community that had taken part in the interviews, as well as nearby neighbourhoods affected by similar problems.

The Història Urbanística tape was shown "nine times in two weeks in various neighborhood assemblies, in the barrio market, at school, and in bars. In all cases, there was a great discussion and mobilization of people around the problem" (Bonet 2010, 253). While information on Spanish TV during the transition period was simply sweetened and positive, showing the process of social transformation in order to guarantee a consensual type of policy (Carrillo 2005, 161), the actions of Video-Nou/SVC-in showing subjects and objects of the city-instead addressed dissent which, as Jacques Rancière states, is the very principle of political action: "The essential work of politics is the configuration of its own space. It is to make the world of its subjects and its operations seen. The essence of politics is the manifestation of dissensus as the presence of two worlds in one" (Rancière 2010, 37). Once again it is a question of representation and responsibility, of a dialogic construction that brings together, in the same common space, two worlds separated by an antagonistic principle, making "visible that which had no reason to be seen" (Rancière 2010, 38).

The experiences of Video-Nou/SVC (initially funded by the Fundació Serveis de Cultura Popular and Col·legi d'Arquitectes de Catalunya) ended in 1983 following the finalisation "of the new process of democratic institutionalization and the emerging centralizing policies of social planning with the ending of the Barcelona City Council's support, framed by the forced and agreed withdrawal of popular protagonism in favor of the new legitimate channels personified by unions and political parties" (Grandas 2017, 25).

\section{Conclusions}

The titles of the three paragraphs, Destroying the Spectatorship, Configuring the Space, and Questioning the Representation, can be read together as a programmatic declaration of a series of actions to be taken into consideration when one is called to confront those practices outlined at the beginning. Among the three, Destroying the Spectatorship is the one action that puts the construction of representation in difficulty the most. In fact, Sontag's reflection must necessarily be coupled with Rancière's. According to the philosopher, this hyper-diffusion of images does not mean that there are "too many images" in an absolute sense: those "too many" are already a partition of all possible images. Specifically, they are a selection made by those who have the power to make those images visible, to ensure that they are disseminated to the detriment of everything else. What we have in front of our eyes is always a "theater of images" because

2. In the Catalan countercultural milieu, the problems related to real estate speculation had been widely discussed in 1977 in Ajoblanco 27 , entitled "Contra la Arquitectura". The dossier contained titles such as: "Manifiesto del diablo sobre Arquitectura y Urbanismo" (Manifesto of the Devil on Architecture and Urbanism), "Me duele la Arquitectura" (My Architecture Hurts), "Las constructoras se lo comen todo" (Construction Companies Eat it All). 


\section{artnodes}

images are always staged (Rancière 2007,71-72). This is particularly true when we face a representation of a city and its architecture, which is a complex object resulting from multiple stratifications of materials, government compromises, market pressures, and social practices. Urban-architectural drawing synthesises it into what we usually call a plan, a map, a chart, or a diagram-each of them an image shaped by a system of coded signs that aim for a precise and punctual realisation of a project, whose aim should be a positive transformation of the quality of life and a more equal redistribution of spaces. But-integrating the thoughts of Baudrillard, Rancière, and Warner-those representations are already precodified signs, preselected images, and preconstituted frameworks that can do nothing but reproduce the same conditions and relations that generated the inequalities in the first place. They voluntarily show what is convenient to see and hear of that complexity. They do not demand an answer, but an execution. Exerting one type of representation only, one that does not require, reject, or deny every possible form of response is a reduction that amplifies the decision-making power of those who already belong to the domains of the visible and audible. It means denying the city its essential political common space. Dries Verhoeven, Jenny Holzer, and Video-Nou, instead, confront us with the representation and ask us for active personal participation in its construction. Here the representation does not take us away from the subjects represented but calls us to respond to them, to consider them part of our bodily universe, as a physical space that we occupy, indeed as a stance.

Verhoeven's work activates the viewer's awareness in such a way that when one is subsequently confronted by advertising imagery, clothing for instance, one can't help but link it to the conditions in their textile factory suppliers, say in Hangzhou. It is a question of making the viewer doubt his position towards image production systems, as well as consumer goods. It is a question of asking ourselves how many and which images have been excluded from the sphere of the visible so that those exploits and working conditions can persevere, leaving our (Western) sensibility unaltered. It may seem somewhat distant from a reflection on the production of images of cities, but these are the same mechanisms that underlie processes, even heterogeneous, of the unequal redistribution of space, such as redlining or "community gating", with which certain bodies are voluntarily turned away and hidden from our senses.

Both Holzer and Video-Nou build, through the moving image, apparatuses capable of making spectators actors, passersby into citizens, and of making their agency visible. However, both actions are not exclusively determined by the media device itself, but by its arrangement in space and its ability to symbolically reconfigure the representation of that space. Specifically, Holzer highlights the discursiveness that is a fundamental characteristic of the public space, too often subtracted and falsely substituted by the televisual image that not only disallows, but rather denies, that reciprocity of symbolic exchange underlined by
Baudrillard; the same self-organised circulation of discourse necessary, for Warner, to break the framework of totalitarianism. The interventions of Video-Nou provoke situations in which bodies take a position in those marginal spaces that one would otherwise wish to be named only as localities of circulation/reproduction of labour (working-class neighbourhoods). But, thanks to those interventions, their visibility is reconfigured as living spaces in which their inhabitants are equally capable and equally entitled to live as those who already thrive in more affluent areas of the city.

In points nine and eighteen of his manifesto on the "expanded" or "total designer", Lluís Ortega writes: "Designers hope for good reviews and approval; total designers are interested in action, not approval. [...] Designers solve problems; total designers generate questions" (Ortega 2017, 72-73). While approval and problem-solving require convincing operations, in order to eliminate the possibility of response, in contrast both action and questioning require participation, argumentation, and comparison. It remains for us to ask how we can effectively respond to the multitude of spectacular images-spawned through new media and social media, multiplied and spread to replace the real world-without the answers being absorbed by the mechanisms of that same spectacularity; and question whether we are able to construct representations capable of generating a response, via researching urban space in a way that does not detach it from politics: preferably a response of dissent.

\section{References}

Ameller, Carles. "Por una comunicación contextual: La experiencia de Video-Nou / Servei de vídeo comunitari." Banda aparte 16 (1999): 45-48.

Baudrillard, Jean. "Requiem for the Media." In Video Culture: $A$ Critical Investigation, edited by John Hanhardt, 124-143. Layton-New York: Peregrine Smith Books-Visual Studies Workshop Press, 1986.

Bonet, Eugeni. "Situación del vídeo en España." In En torno al vídeo, edited by Eugeni Bonet et al. Bilbao: Servicio Editorial de la Universidad del País Vasco, 2010.

Buchloh, Benjamin H. D. "From Gadget Video to Agit Video: Some Notes on Four Recent Video Works." Art Journal 45, no. 3 (1985): 217-227. D0I: https://doi.org/10.2307/776856

Butler, Judith. L'alleanza dei corpi: Note per una teoria performativa dell'azione collettiva. Translated by Federico Zappino. Milan: Nottetempo, 2017.

Carrillo, Jesús, ed. Desacuerdos: Sobre arte, políticas y esfera pública en el Estado español 3. Barcelona: MACBA, 2005.

Cavalletti, Andrea. La città biopolitica: Mitologie della sicurezza. Milan: Mondadori, 2005.

Debord, Guy. La società dello spettacolo. Translated by Paolo Salvadori. Milan: Baldini \& Castoldi, 2013. 


\section{artnodes}

https://artnodes.uoc.edu

The Video, the City, and the Spectator: Architecture and Its Bodies in Front of a Video Camera

Elcott, Noam M. "The Phantasmagoric Dispositif: An Assembly of Bodies and Images in Real Time and Space." Grey Room 62 (2016): 32-71. DOI: https://doi.org/10.1162/GREY_a_00187

Escobar, Esteban. "L'experiència del Servei de Vídeo Comunitari a Barcelona." Ciència 2, no. 7 (1981): 22-25.

Grandas, Teresa, ed. The Hard Gelatin. Hidden Stories from the 80 s. Barcelona: MACBA, 2017.

Joselit, David. Feedback: Television Against Democracy. CambridgeLondon: The MIT Press, 2007.

Ortega, Lluís. The Total Designer. Authorship in Architecture in the Post-Digital Age. Barcelona-New York: Actar Publishers, 2017.

Public Art Fund. "Jenny Holzer: Sign on a Truck." Accessed September 20, 2019. https://www.publicartfund.org/exhibitions/ view/sign-on-a-truck.

Rancière, Jacques. Disagreement: Politics and Philosophy. Translated by Julie Rose. Minneapolis-London: University of Minnesota Press, 1999.
Rancière, Jacques. Ai bordi del politico. Translated by Andrea Inzerillo. Naples: Cronopio, 2001.

Rancière, Jacques. "Theater of Images." In Alfredo Jaar: The Politics of Images, edited by Georges Didi-Huberman, 71-80. Zürich: JRPIRingie, 2007.

Rancière, Jacques. Dissensus: On Politics and Aesthetics. LondonNew York: Continuum Publishing, 2010.

Schütz, Theresa. "Immersive Guilt Factories." In Staging Spectators in Immersive Performances, edited by Doris Kolech et al., 180-187. Abingdon-New York: Routledge, 2019.

Sontag, Susan. Regarding the Pain of Others. London: Penguin Books, 2003.

Tschumi, Bernard. The Manhattan Transcripts. London: Academy Editions, 1994.

Warner, Michael. Publics and Counterpublics. New York: Zone Books, 2002. 


\section{artnodes}

\section{CV}

\section{Lorenzo Lazzari}

University of Udine

lazzari.Iorenzo@spes.uniud.it

Lorenzo Lazzari is interested in the relationship between the moving image and politics. His research is about those forms of display capable of generating dissent, questioning normalising patterns. He is currently studying towards a PhD in Art History, Film and Media Studies at the University of Udine. 